optimistic account of the fire, and accompany it with a view of the Observatory buildings and house.

"It came at last. On Sunday morning, the I7th February, at 7.30 a.m., I was alarmed by the cry of fire, and at 8 o'clock I was looking at smoking ruins in the midst of my two armsful of salvage (which I took good care should include my last year's photographic records), receiving cards of condolence from high personages and presents from the neighbouring shop-keepers-like bottles of beer, boxes of eggs, and oranges-and all this while the fire engines were vigorously pumping. I saw that nothing more was to be saved, but before the flames were out, my colleague, Mr. C. D. West, set to work to take a series of snap-shots with his hand-camera. The results look like fogged plates, but they show amongst other things the effects of heat upon my big stone column. On Tuesday, I used some of the pieces as illustrations to a geological class as illustrative of the action of lava streams upon rocks they occasionally flow over. The President of the University, who very kindly had hurried from his house to see me and my ruins, had a new house ready for me before my own had done smoking, and I am now in it arranging furniture I have hired, sorting through heaps of charred paper, and getting ready to set up two new pendulums. These latter, if they work well, I hope to bring with their records to England, to show as a type of instrument which may be able to record movements which go round the globe and possibly through its interior. When earthquakes are recorded throughout Great Britain, it will not be necessary to always introduce a conversation with remarks about the weather.

"As nearly all the Transactions of the Seismological Society were packed up to go to Europe, a few that had middle places in the boxes may be saved, but I doubt if even out of 2500 copies I shall get more than two or three hundred. All my old earthquake books, some of which even dated from 1500 and 1600 , but which were perhaps more curious than useful, seem to have gone.

"Instruments were fused or vapourised. Sixteen specially constructed clocks, which would turn drums once a day, once a week, or drive a band of paper for two years, together with seismographs and horizontal pendulums, self-recording thermometers and barometers, microscopes, and a museum of old and new contrivances, are now on the scrap heap. Until to-day, I felt that $I$ had the observatory I intended to put up in England completely furnished, and I was proud of the furniture.

"The fire broke out in the midst of a pile of wood in an out-house, and this with a nice wind blowing on a Sunday morning when there was no one near to help.

"And now I have next to nothing-decorations, medals, diplomas, clothes, manuscripts, extending over twenty-five years, and everything else has gone to smoke ; still it is not altogether a misfortune.

"Looked at in the right way, like an earthquake, a fire may after all be a blessing in disguise ; but, of course, it is sometimes pretty well wrapped up.

"Dies iræ, dies illa,

Solvet saeclum in favilla."

\section{TERRESTRIAL HELIUM?}

HAVE received the following letter and enclosure from Prof. Thorpe :-

$$
\text { "University of Glasgow, April } 16 .
$$

"MY DEAR LOCKYER,-The enclosed extract from a letter just received from Cleve of Upsala may be of interest to you.

$$
\text { "Ever yours, }
$$
"T. E. THORPE."

"I have got from Mr. Crookes a letter in which he informs me that the gas in Cleveite contains the longsearched for helium.

$$
\text { No. I329, voL. } 5 \text { I] }
$$

"This letter arrived exactly the very day one of my pupils, Mr. Langlett, tried to get the gas of Cleveite in my laboratory. The gas given off from my mineral did not contain a trace of argon. The spectrum has been examined by Thalen, who found an exact coincidence of

\begin{tabular}{|c|c|c|c|c|c|}
\hline Wave-length. & & & & & $\begin{array}{l}\text { Intensity. } \\
\text { half-strong }\end{array}$ \\
\hline $\begin{array}{l}6077 \\
5875.9\end{array}$ & $\cdots$ & $\begin{array}{l}\cdots \\
\cdots\end{array}$ & $\begin{array}{l}\cdots \\
\ldots\end{array}$ & $\cdots$ & $\begin{array}{l}\text { halt-strong } \\
\text { strong: helium }\end{array}$ \\
\hline 5048 & $\ldots$ & $\ldots$ & $\ldots$ & $\ldots$ & half-strong \\
\hline 5016 & $\ldots$ & .. & $\ldots$ & $\ldots$ & strong \\
\hline 4922 & $\ldots$ & $\ldots$ & $\ldots$ & $\ldots$ & half-strong \\
\hline 4713.5 & $\ldots$ & $\ldots$ & $\cdots$ & $\ldots$ & weaker \\
\hline
\end{tabular}
the line of the gas with the helium line and besides some others :-

"I have sent a letter about it to Berthelot. If you like, you may communicate the result to the Chemical Society, Mr. Ramsay, Crookes, and other friends. . . . An experiment to determine the specific gravity did not give trustworthy results, but seems to indicate that it is a very light gas, still more heavy than hydrogen. Will this gas fill the gap between hydrogen and lithium? It will become very interesting to see. What makes me much curious is that our helium gas was free from argon, and that Mr. Ramsay's (according to Comptes rendus) did contain that curious stuff. Is there any relation between argon and helium, and are we facing a new epoch in chemistry?"

Although my results are not yet complete for publication, the foregoing communication makes it desirable that I should state at once that immediately on the publication of Prof. Ramsay's statement, by the kindness of Mr. L. Fletcher I was enabled to study the gases given off by Cleveite by heating in vacuo, a method I have used for metals and meteorites.

A very small quantity of Cleveite is all that is necessary to obtain a considerable volume of the new gas, which comes off associated with hydrogen.

I have now examined several tubes. I have found no argon lines; I have not found the lines, other than the yellow one, given by Crookes; but lines have been recorded near some of the wave-lengths given by Thalén, especially the one at 6677 , near a line I discovered in the chromosphere in 1868. So far the sky has not been clear e nough to enable me to determine by direct comparison with the chromosphere the position of the line in the yellow with great dispersion.

\section{J. NORMAN LOCKYER.}

\section{NOTES.}

IN honour of $M$. Berthelot, and as a demonstration of the power and progress of science in France, a banquet was held at Paris a few days ago. Nearly eight hundred guests were present, among them being $M$. Brisson, President of the Chamber of Deputies, and M. Poincaré, Minister of Public Instruction. Upon the invitation cards were printed the words: " Hommage à la science, source de l'affranchissement de la pensée." M. Poincaré made an eloquent speech in praise of the work done by the eminent Secretary of the Paris Academy of Sciences, and M. Berthelot, in his reply, dwelt, at some length, upon the beneficial influence of science on social and moral, as well as material, progress. Science, he said, had for its only guide the love of truth, and confidence in its final triumph. Proved under all circumstances, and strengthened every day by success, the scientific method had become the principal source of the moral and material progress of society. In fact, science was the source of all progress accomplished by the human race. Every one knew that, during this century 